\title{
Nerede O Eski Mutfaklar
}

\section{Where Were The Old Kitchens}

\author{
Prof. Dr. Mehmet Oğuzhan İLAN \\ Balıkesir Üniversitesi \\ Öğr. Gör. Dr. Ceren ULUER SAVGIN \\ Burhaniye Uygulamalı Bilimler \\ Balıkesir Üniversitesi \\ Yüksekokulu, \\ Burhaniye Meslek Yüksekokulu, \\ Balıkesir, Türkiye \\ E-posta: ilban@balikesir.edu.tr \\ Balıkesir, Türkiye \\ E-posta: cerenuluer@gmail.com
}

\section{Öz}

$\mathrm{Bu}$ araştırmanın amacı geçmişten bugüne kırsal alanlarda mutfak kültürü öğelerinin değişimini incelemektir. Çalışmada nitel araştırma yöntemlerinden görüşme tekniği kullanılmıştır. Balıkesir ili Burhaniye kırsal alanlarında yarı yapılandırılmış görüşme formu ile veri toplama işlemi gerçekleştirilmiştir. Ayrıca gözlemler yapılarak mutfak yerleşim düzeni, pişirme alanları ve kullanılan ekipmanlar incelenmiştir. Katılımcılarla gerçekleştirilen görüşmelerden elde edilen veriler kullanılarak içerik analizi ve betimsel analiz yapılmıştır. Araştırma sonuçlarına göre mutfak yerleşim düzeni geçmişte bahçede yer alırken günümüzde ev içerisinde yer almaktadır. Ayrıca yapılan araştırmada geçmişte yer sofrasında ve ayrı tabak olmadan yemek yendiği ve yemeklerin daha az çeşit olmasının yanı sıra daha lezzetli olduğu gibi sonuçlar ön plana çıkmıştır. Bu değişimlerin yanında kırsal alanlarda yaşayanlar halen geleneksel gıda saklama yöntemlerini kullanmaktadırlar. Genellikle konserve, kurutma ve reçel yöntemlerini kullanmaya devam etmekte ayrıca tarhana ve erişte yapmaktadırlar.

Anahtar Kelimeler: Mutfak kültürü, Yöresel mutfak, Kırsal alan.

\section{Abstract}

The aim of this research is to examine the changes in the elements of culinary culture in rural areas from the past to the present. Interview technique, is one of the qualitative research methods, was used in the study. Data collection was carried out with semistructured interview form in rural areas of Burhaniye in Balıkesir province. In addition, the kitchen layout, cooking area sand the equipments used were examined. According to the results of the research, the kitchen layout was in the garden in the past and nowadays it is in the house. In addition, the results of the study revealed that in the past it was eaten at the table and without separate plates and the food was less varied but more delicious. In addition to these changes, people living in rural areas are stil using traditional food preservation methods. They generally continue to use canning, drying and jam methods as well as making tarhana and noodles.

Key Words: Culinary culture, Local cuisine, Rural area. 


\section{Giriş}

Mutfak kültürü ait olduğu toplumların yaşama kültürünü içeren önemli bir kültür mirasıdır. Günümüzde hızıı bir değişim içerisinde olan mutfak kültürü kavramı kırsal alanlarda kentlere göre nispeten daha az değişikliğe uğramıştır. Kırsal alan; idari sınırlar itibarıyla nüfus yoğunluğu $\mathrm{km}^{2}$ başına 150 kişiden daha az olan yerleşim yerleri olarak kabul görmektedir. Bölgeler, kırsal nüfus büyüklüklerine göre; çoğunlukla kırsal bölge ve kentsel bölge olarak ifade edilmektedir (Tarım ve Köy İşleri Bakanlığı, 2011: 39).

Bir yörenin sahip olduğu iklim şartları, coğrafi koşullar, bölgeye has özellikler ile ortaya çıkan yöreye özgü yemeklerin oluşturduğu bir kavram olan yöresel mutfaklar, bölge halkı için olduğu kadar, bölgeyi ziyaret eden turistler için de öneme sahiptir (Şengül ve Türkay, 2016,91).Mutfak kültürü, sosyo-kültürel açıdan bir ulusun ve kültürün özgün yönünü oluşturmakla birlikte ulusları birbirine kaynaştıran bir araç olarak da değerlendirilmelidir. Yiyecekler farklı kültürleri anlamaya yardımcı temel işaretlerdendir çünkü yiyecek hazırlama, dağıtımı ve tüketimi, her toplumda toplumsal ilişkilerin egemen tipini yansıtır (Tezcan,1993). Kökleri eskilere dayanan Türk mutfağının geçmişten bugüne çeşitli biçimlerde geliştiği ve yenilendiği görülmektedir. Dolayısıyla Türk mutfağında yer alan tatların geçmişten günümüze aktarımını sağlayabilmek adına bu alanda çalışmalar yapmak oldukça önemlidir (Önçel, 2015). Bununla beraber mutfak kültürü kavramının diğer unsurlarından biri olan mutfak düzeni, kullanılan araç gereçler gibi ögeler de unutulmamalıdır. Yöresel mutfak kültürü, diğer çekicilikleri tamamlayıcı bir unsur olarak kabul edilebilir. Bunun yanında bağımsız bir cazibe unsuru olarak destinasyonların başarısına katkıda bulunmak için kullanılabilir ve bir turizm ürününün temel bir cazibe unsuru olarak da ele alınabilir (Henderson, 2009).

Yapılan çalışmalar incelendiğinde çalışmaların genelde mutfak kültürü ile ilgili olduğu, mutfak kültürü denince de ağırlıklı olarak yöresel yemeklerin incelendiği görülmektedir (Güneş, Ülker ve Karakoç, 2008; Şanlıer, Cömert, Durlu, Özkaya,2012; Şengül, Türkay 2016; Babat, Gökçe ve Varışlı, 2017; Demirel ve Ayyıldız, 2017; Çakıcı, Zencir 2017). Oysa mutfak kültürü kavramı; pişirme alanları, yemek yapımında kullanılan araç gereçler, sofrada kullanılan kaplar, sofra oturma düzeni gibi unsurlar da ele alınmalıdır. Ayrıca kırsal alanlara yönelik bu konuda yapılan çalışmalar oldukça sınırlıdır.

Bu çalışma da diğer çalışmalardan farklı olarak mutfak kültürü kavramı kırsal alanlarda incelenmiş ve mutfak kültüründeki değişimi tespit edilmeye çalışılmıştır. Hızlı kentleşme ve kadının çalışma hayatına girmesi kuşkusuz mutfak kültüründe hızlı bir değişime sebep olmuştur. Şehirlerde durum böyle iken kırsal alanlarda mutfak kültürünün geçmişten günümüze ne durumda olduğunu ortaya koymak önem arz etmektedir. Yapılan çalışmada katıımcıların sadece bugünü değil çocukluğundaki mutfak kültürünü günümüz ile karşılaştırarak geçmiş ile bugün arasında ki farkları aynı kişilerin ağzından ortaya konulması amaçlanmıştır. Çalışma da ayrıca kırsal alanlarda mutfak kültüründe, mutfak düzeni ve mutfak araç gereçlerinde meydana gelmiş olan değişikliklerin tespiti ve geleneksel dokunun korunmasına yönelik öneriler geliştirilmesi de amaçlanmaktadır. Mutfak kültürü ülkenin, bölgenin ve yöre halkının yaşam kültürünü de içinde barındıran korunması gereken bir kültür mirası niteliğindedir. Kentlerde mutfak kültürü hızlı bir değişim geçirmiştir. Ancak kırsal alanlarda da durumun ne olduğunun belirlenmesi mutfak kültürünün korunması ve gelecek nesillere aktarılması açısından önem arz etmektedir. 


\section{Alan Yazın}

Alan yazında mutfak kültürü konusundaki araştırmalar incelendiğinde geçmişten bu güne mutfak kültürünü ele alan çalışma sayısı oldukça azdır. Ancak mutfak kültürü kavramını çeşitli bakış açıları ile ele alan çalışmalardan bazılarına bu bölümde yer verilmiştir. Gvion ve Trostler (2008) da çalışmalarında mutfak kültürü kavramını, bir yemek için gerekli olan malzemelerin, yemeğin sunumunun, pişirme şekillerinin ve nasıl yenmesi gerektiğinin toplamı olarak ifade etmişlerdir. Doğdubay ve Giritlioğlu (2011) mutfak kültürü kavramını daha geniş bir şekilde ele alarak; beslenmeyi sağlayan yiyecek-içecek türleri ve bunların hazırlanma, pişirilme, saklama süreci; kullanılan mekân ve ekipman, yeme içme geleneği ile bu çerçevede gelişen gelenek ve uygulamalardan meydana gelen kendine özgü kültürel yapıyı ifade ettiğini belirtmişlerdir.

Mutfak kültürünün geleceğe aktarılması kuşkusuz sürdürülebilirliğinin sağlanması ile mümkündür. Babat, Gökçe ve Varışlı (2017) yaptıkları çalışmada Hatay mutfak kültürünün sürdürülebilirliğinde, yöresel yiyecek üreticilerinin rolünü incelemiştir. Bozok ve Kahraman (2015) çalışmalarında kırsal turizmin gelişmesinin işletmelerde sunulan ürün çeşitliliğinin artmasına, saklı kalmış geleneksel lezzetlerin gün yüzüne çıkarılmasına ve yerel ekonominin gelişmesine katkı sağlayacağını vurgulamışlardır. Güneş, Ülker ve Karakoç (2008); mutfak kültürünü sürdürülebilir turizm açısından değerlendirmişler ve yöresel yemeklerin korunarak gelecek nesillere aktarılabilmesinin önemli yollarından birinin turistik ürün olarak kullanımı olduğunu ifade etmişlerdir. Dolayısıyla kırsal yörelerde saklı kalmış unutulmaya yüz tutmuş yöresel yemekler mutfak kültürü unsurları da bu şekilde geleceğe aktarılabilecektir. Şanlıer, Cömert, Durluve Özkaya (2012) çalışmalarında; gençlerin Türk mutfak kültürü hakkındaki görüşleri ile belirli yöresel yemekleri sevme ve özel gün yemeklerinin ailelerinde yapılma durumlarını incelemişlerdir. Türk mutfak kültürünü mizahi yönleri ile inceleyen, geçmişten günümüze nasıl geliştiğini, turizm işletmeleri içerisinde Türk mutfağının nasıl tanıtıması ve pazarlanması gerektiğini aktaran başka bir çalışmayı da Önçel (2015) gerçekleştirmiştir.

Mutfak kültürü öğeleri yörelerin çekiciliğini de arttırmaktadır. Lopez ve Martin, (2006) yaptıkları çalışmalarında toplumları ve bölgeleri daha yakından tanıyabilmek adına yemeklerin ve mutfak özelliklerinin bir araç olduğunu belirtmektedir. Bu sebeple son yıllarda yiyecekler, seyahat deneyiminin giderek merkezinde yer almaktadır. Mutfak kültürü kavramı denince akla, yalnızca yemek çeşitlerinin değil aynı zamanda bu yiyeceklerin pişirme öncesi hazırlığı, pişirimi, sunumu ve saklanmasına yönelik teknikler ile servis esnasında tercih edilen araç ve gereçler, mutfağın konumu ve mimarisi, yemek törenleri ve bu hususta gelişen inanç ve uygulamaları da kapsayan bir kültürel yapı akla gelmelidir (Durlu, Özkaya ve Kızılkaya 2009:266).

Yemek için kullanılabilecek araç ve gereçlerin evin farklı bir kısımda (mutfak) kullanılmaya başlaması insanoğlu için yedinci y.y.'dan sonra meydana gelmektedir (Önçel, 2015). Geçmiş dönemlerde evin içi yerine, dışarıda, avluda ya da evlerin alt katlarında mutfaklar yer almaktaydılar. Bu tip yapılar Anadolu'nun kimi yerlerinde hala gözükmektedir. Yörelere ve bölgelere göre mutfaklar değişiklik gösterdiği için Anadolu için tek bir mutfak tipinden bahsetmek doğru değildir. Tek bir mutfak tipi olmadığı gibi pişirme yöntemlerinin de tek tip olması olası değildir. Bu nedenle pişirme yöntemleri arasında yer alan tandır da yörelere göre farklılık göstermektedir. Kimi yörelerde tandır için ayrı bir oda ya da tandır evleri varken kimi yörelerde de mutfağın içerisinde yer almaktadır (Önçel, 2015). Mutfaklarda yemek ve ekmek pişirilmesi için ocaklar ve tandır kullanılmaktadır. Fırın tandır; ısıya dayanıklı tandır taşlarının örülmesi ile çömlek 
biçiminde killi kırmızı topraktan hazırlanan çamur ile yapılan tandır olarak tanımlanabilmektedir(Köşklü, 2005;156). Ocaklar ve tandırlar da bulunduğu yöreye göre farklıııklar göstermektedir. Örneğin; tandırlar bazı yörelerde mutfak içinde, bazı yörelerde de bahçede ayrı bir alanda yer almaktadır. Bazı yörelerde toprak sıva bahçe tandırlar mevcutken daha soğuk yörelerde toprak içinde gömme tandırlar bulunmaktadır (Savgın ve Zengin, 2019).Büyük evlerde her gün yemek yapmak ve sıcak su bulundurmak için her gün yakılan "küçük tandır", on beş günde bir ekmek yapmak, çamaşır yıkamak, belli dönemlerde kavurma yapmak, yağ eritmek için ise "büyük tandır" bulunmaktadır (Çomaklı, 2011;333).

Mutfakta kullanılan araçlardan biri de üzerinde yemek servisi yapılan sinidir. Geçmişte yemek vakti geldiğinde, "sini" denilen yuvarlak tablalar etrafında toplanılırdı. Siniler en fazla beş yada altı kişilik olmaktaydı. Sininin üzerinde, örtü, tabak, çatalbıçak bırakılmazdı, yemek elle yenir, çatal ve bıçak kullanılmazdı. Günümüzde bu alışkanlığın yerini masada ayrı kaptan yemek yemeye bıraktığını görmekteyiz. Bu gün bile hala, kırsal kesimin büyük bir çoğunluğunda, sini etrafında yemek yeme alışkanlığı bulunmaktadır. Günümüzde kırsal kesimde büyük oranda aileler sofraya konan ortak bir kaptan yemek yemektedir. Şehirleşme arttıkça herkese ayrı bir tabak içinde yemek servisinin yapıldığı sofraların daha yaygın olduğunu söyleyebiliriz (Güler,2010). Bununla birlikte Türk mutfağında tüketimde bazı keskin ayrımlar da bulunmaktadır. Kırsal alanlarda daha çok evde hazırlanan tarhana, pekmez, erişte, peynir, turşu, kuru sebze ve meyveler, bulgur gibi yiyeceklerin tüketildiği görülmektedir. Bunun yanında, şehirlerde ise, büyük marketlerde satılan hazır yiyeceklerin tüketilmesi dikkat çekmektedir (Serçeoğlu, 2014).Özellikle kadınların da iş hayatına girmesinin hazır gıdaya yönelimde önemli payı olduğunu belirtebiliriz.

Mutfak kültürü, çevrede yetişen bitkilere, toprak yapısına, iklim ve coğrafyaya kadar birçok faktörün etkisi altında gelişmiştir. Bu etkenler doğrultusunda mutfak kültürü de ülkelere, bölgelere ve yörelere göre farklılıklar göstermekle beraber mutfak yerleşim düzeni ve kullanılan ekipmanlar değişiklik gösterebilmektedir. Bu çalışma ülkemizde kırdan kente göç sebebiyle unutulmaya yüz tutmuş geleneksel mutfak kültürü ögelerinin incelenmesini amaçlamaktadır.

\section{Yöntem}

Çalışmada nitel araştırma yöntemi kullanılmıştır. Nitel araştırma; gözlem, görüşme ve doküman analizi gibi nitel veri toplama yöntemlerinin kullanıldığı, algıların ve olayların doğal ortamda gerçekçi ve bütüncül bir biçimde ortaya konmasına yönelik nitel bir sürecin izlendiği araştırma olarak tanımlanabilir (Yıldırım ve Şimşek, 2008: 39). Araştırmada amaçlı örnekleme yöntemlerinden kartopu ve uç örnekleme tekniği kullanılmıştır. Araştırmanın problemine ilişkin olarak zengin bilgi kaynağına ulaşılabilecek bireylerin tespitinin sağlanabilmesi için bu yönteme başvurulmuştur (Patton, 2005). Uç örneklem için önceden belirlenen Burhaniye kırsalında ve Madra Dağı eteklerinde yer alan köy muhtarlarından isimler istenmiş ve önerilen isimlerle görüşmeler yapılmıştır. Kartopu örneklem için ise her bir köyde yapılan görüşmelerde "bu konuyla ilgili başka kimler ile görüşebiliriz?" bu konuda en çok bilgi sahibi kimler olabilir?" sorularına verilen cevaplardaki isimler araştırmaya dahil edilmiş en fazla hangi isimler verilmiş ise onlarla görüşülmüş her bir görüşmede kartopu gibi örneklem büyümüş ve aynı isimler tekrarlanmaya başlandığında görüşmelere son verilmiştir. Çalışmanın uygulanabilmesi için gerekli olan etik kurul izni Balıkesir Üniversitesi Sosyal ve Beşeri Bilimler Etik Komisyonunun 09.06.2020 tarihli ve 2020/6 sayılı toplantısında alınmıştır. Araştırma kapsamında 04.06.2019 tarihi ile 15.05.2019 tarihi aralığında Balıkesir'in Burhaniye İlçesi kırsalında yer alan; Avunduk, Bahadınlı, Çallı, 
Sarılar /Damlalı, Sübeylidere, Karadere ve Kuyucak köylerine gidilerek yarı yapılandırılmış görüşme formları ile mülakat ve gözlemler gerçekleştirilmiştir. Katılımcılar ile yapılan görüşmelerde ses kaydı alınmış ve daha sonra elde edilen ses kayıtları yazılı doküman haline getirilmiştir. Görüşme yapılan katılımcılar K1, K2, K3 ......ve K19, K20 şeklinde kodlanmıştır. Veriler toplanırken sorulara verilen cevaplarda hiçbir yeni bilgi elde edilmiyor ise bu durumda araştırmada doygunluğa ulaşılmış (Morse, 1995:147) olarak kabul edilmiştir. Bu nedenle araştırmada verilen cevapların bir noktadan sonra tekrar ettiği ve yeni bilgiler elde edilmediği için çalışma 20 katılımcı ile tamamlanmıştır.

Yarı yapılandırılmış görüşme formundaki sorular temalara göre hazırlanmıştır. Hazırlanan görüşme formu alanında uzman kişilere gönderilerek önerileri alınmış ve bu doğrultuda soru formu revize edilmiştir. Katılımcılarla gerçekleştirilen görüşmelerden elde edilen veriler kullanılarak betimsel analiz ve içerik analizi yapılmıştır. Betimsel analiz yönteminde; elde edilen veriler, daha önce belirlenmiş başlıklar altında (temalar gibi) özetlenmekte ve yorumlanmaktadır (Coşkun ve diğ., 2015: 324).Betimsel analizle özetlenen ve yorumlanan veriler, içerik analiziyle derinlemesine bir işleme tabi tutulur ve yeni kavramlar keşfedilir. İçerik analizinde temel amaç, toplanan verileri açıklamaya yardımcı olacak kavramlara ve ilişkilere ulaşmakdır. İçerik analizinde temelde yapılan işlem, birbirine benzeyen verileri belirli kavramlar ve temalar çerçevesinde bir araya getirmek ve bunları okuyucunun anlayabileceği bir biçimde düzenleyerek yorumlamaktır. (Yıldırım ve Şimşek, 2008: 227; Neuman, 2012: 663).

Kırsal alanların genellikle coğrafi açıdan zorlu yörelerde yer almaları ve yaşayan halkın iş yüklerinin fazla olması bu çalışmada önemli kısıtılıklardır. Ayrıca Türkiye çapında kırsal alanlara ulaşarak araştırmanın uygulanabilmesi maliyet açısından da bir kısıt teşkil etmektedir. Katılımcılara yöneltilen sorular, ilgili alanyazın incelemesi ve alanında uzman kişilerin bilgisine başvurularak oluşturulmuştur. Katılımcılara yöneltilen sorularda yeterli cevap alınamadığı zamanlarda, yeni sorular türetilmiş ve bu sayede derinlemesine bilgiye ulaşılmıştır. Görüşmeler sırasında ses ve görüntü kaydı alınmıştır. Katılımcıların bazılarının ses kaydı alınmasını kabul etmemesi durumunda, edinilen bilgiler not almak suretiyle kayıt altına alınmıştır.

\section{Bulgular ve Tartışma}

$\mathrm{Bu}$ bölümde katılımcılar ile ilgili genel bilgilere yer verilmiştir. Bu kapsamda katılımcılara; yaşı, öğrenim durumu, mesleğine dair sorular yöneltilmiştir.

Tablo 1: Katılımcılara Ait Tanımlayıcı Bilgiler

\begin{tabular}{|l|c|c|}
\hline Meslek & $\mathbf{N}$ & $\%$ \\
\hline Ev hanımı & 17 & 85 \\
\hline Esnaf & 2 & 10 \\
\hline İşletmeci & 1 & 5 \\
\hline Toplam & 20 & $\mathbf{1 0 0}$ \\
\hline Yaş & $\mathbf{N}$ & $\%$ \\
\hline $35-40$ yaş aralığı & 5 & 25 \\
\hline $41-45$ yaş aralığı & 3 & 15 \\
\hline $46-50$ yaş aralığı & 1 & 5 \\
\hline $51-55$ yaş aralığı & 3 & 15 \\
\hline $56-65$ yaş aralığı & 6 & 30 \\
\hline $65-$ üzeri & 2 & $\mathbf{1 0}$ \\
\hline Toplam & $\mathbf{2 0}$ & $\mathbf{1 0 0}$ \\
\hline
\end{tabular}


Tablo 1'in devamı

\begin{tabular}{|l|c|c|}
\hline Öğrenim Durumu & $\mathbf{N}$ & $\%$ \\
\hline Yok & 3 & 15 \\
\hline Illkokul & 11 & 65 \\
\hline Ortaokul & 1 & 5 \\
\hline Lise & 4 & 20 \\
\hline Lisans & 1 & 5 \\
\hline Toplam & $\mathbf{2 0}$ & $\mathbf{1 0 0}$ \\
\hline
\end{tabular}

Araştırmaya dahil olan katılımcıların önemli bir bölümü ilkokul mezunu, \%20'sinin de lise mezunu olduğu görülmektedir. Araştırmaya katılanların büyük çoğunluğu ev hanımıdır. Katılımcıların önemli kısmı 50 yaşın üzerindedir. Bu da mutfak kültürünün sadece bugününü değil; katılımcıların çocukluğundaki mutfak kültürünü günümüz ile karşılaştırarak geçmiş ile bugün arasında ki farkları aynı kişilerin ağzından ortaya konması açısından önemlidir.

Araştırma kapsamında sorulan sorulara yönelik alınan cevaplar aşağıdaki şekilde temalara ve bu temalarla bağlantılı alt temalara ayrılarak yorumlanmıştır.

Tema 1:Mutfak Yerleşim Düzeni ve Kullanılan Ekipmanlar

Tema 2:Mutfak Kültürünün Sürdürülebilirliği

Tema 3:Yöresellik ve Geçmişten İzler

Tablo 2: Mutfak Yerleşim Düzeniyle Kullanılan Ekipmanlara İlişkin Cevaplar

\begin{tabular}{|c|c|c|c|c|c|}
\hline 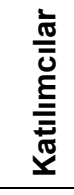 & 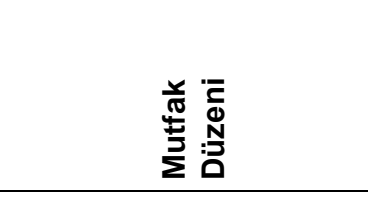 & 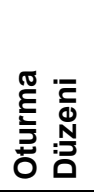 & 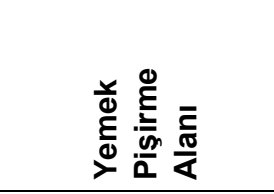 & 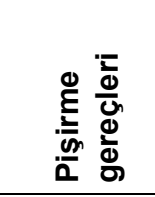 & 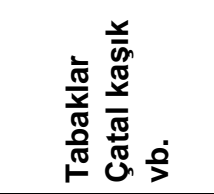 \\
\hline K1 & Ev içi mutfak & Yok & Ev içi mutfakta & - & - \\
\hline K2 & Ev içi ve Bahçede mutfak & Var & $\begin{array}{c}\text { Toprak sıva bahçe } \\
\text { tandır }\end{array}$ & Kara tava & $\begin{array}{l}\text { Porselen - } \\
\text { metal }\end{array}$ \\
\hline K3 & Ev içi mutfak & Yok & Ev içi mutfakta & & $\begin{array}{c}\text { Metal çatal } \\
\text { kaşık }\end{array}$ \\
\hline K4 & Ev içi mutfak & Var & $\begin{array}{c}\text { Toprak sıva bahçe } \\
\text { tandır }\end{array}$ & $\begin{array}{c}\text { Toprak- } \\
\text { bakır }\end{array}$ & - \\
\hline K5 & Ev içi ve Bahçede mutfak & Var & $\begin{array}{c}\text { Toprak sıva bahçe } \\
\text { tandır }\end{array}$ & Güveç & Çömlek- bakır \\
\hline K6 & Ev içi ve Bahçe mutfak & Var & $\begin{array}{c}\text { Toprak sıva bahçe } \\
\text { tandır }\end{array}$ & Güveç & Bakır- ahşap \\
\hline K7 & Ev içi ve Bahçe mutfak & Var & $\begin{array}{c}\text { Toprak sıva bahçe } \\
\text { tandır }\end{array}$ & - & - \\
\hline K8 & Ev içi ayrı mutfak & Var & $\begin{array}{c}\text { Toprak sıva bahçe } \\
\text { tandır }\end{array}$ & $\begin{array}{l}\text { Çömlek } \\
\text { güveç }\end{array}$ & Ahşap kaşık \\
\hline K9 & Ev içi mutfak & Var & $\begin{array}{l}\text { Toprak sıva bahçe } \\
\text { tandır }\end{array}$ & - & Ahşap kaşık \\
\hline K10 & Ev içi mutfak & Var & Ev içi mutfakta & Metal & Metal \\
\hline
\end{tabular}


Tablo 2'nin devamı

\begin{tabular}{|c|c|c|c|c|c|}
\hline K11 & Ev içi mutfak & Var & Ev içi mutfakta & $\begin{array}{c}\text { Çömlek } \\
\text { emaye } \\
\text { kazan }\end{array}$ & Metal \\
\hline K12 & Ayrı mutfak & Var & Mutfakta & $\begin{array}{l}\text { Güveç- bakır } \\
\text { tepsi-çelik }\end{array}$ & $\begin{array}{c}\text { Ahşap ve } \\
\text { metal }\end{array}$ \\
\hline K13 & Ev içi ve Bahçe mutfak & Var & $\begin{array}{c}\text { Toprak sıva bahçe } \\
\text { tandır }\end{array}$ & - & - \\
\hline K14 & Ev içi ve Bahçe mutfak & Var & $\begin{array}{c}\text { Toprak sıva bahçe } \\
\text { tandır }\end{array}$ & $\begin{array}{c}\text { Bakır kap ve } \\
\text { cezve }\end{array}$ & - \\
\hline K15 & Ev içi mutfak & Var & $\begin{array}{c}\text { Toprak sıva bahçe } \\
\text { tandır }\end{array}$ & Bakır & Çelik metal \\
\hline K16 & Ev içi ve Bahçe mutfak & Var & $\begin{array}{c}\text { Toprak sıva bahçe } \\
\text { tandır }\end{array}$ & Bakır güveç & Ahşap \\
\hline K17 & Ev içi mutfak & Var & $\begin{array}{c}\text { Toprak sıva bahçe } \\
\text { tandır }\end{array}$ & - & - \\
\hline K18 & Ev içi ve Bahçe mutfak & Var & Ev içi mutfakta & - & Ahşap \\
\hline K19 & Ev içi mutfak & Var & Ev içi mutfakta & - & $\begin{array}{l}\text { Porselen- } \\
\text { metal }\end{array}$ \\
\hline K20 & Ev içi ve Bahçe mutfak & Var & Ev içi mutfakta & - & Metal \\
\hline
\end{tabular}

Tablo 2'ye göre ;K1, K3, K4, K9, K10, K11, K15, K17, K19 ev içerisinde ayrı oda şeklinde mutfak düzenlemesine sahip bir evde yaşamaktadır. ; K2, K5, K6, K7, K13, $\mathrm{K} 14, \mathrm{~K} 16, \mathrm{~K} 18, \mathrm{~K} 20$; hem ev içerisinde hem de bahçede mutfak düzenlemesine sahiptir.Ev içerisinde mutfak varken bahçede de mutfak düzenlemesinin halen sürdürülüyor olması değişime ayak uydurmakla beraber halen geçmiş kültüründe sürdüğünün göstergesidir. Ayrıca, K2, K4, K5, K6, K7, K8, K9, K13, K14, K15, K16, K17 katılımcılarının mutfak pişirme düzeni haricinde bahçelerinde "toprak sıva bahçe tandırı" bulunmaktadır. Katılımcılar yemek pişirme araç gereci olarak çömlek ve toprak kapları halen kullandıklarını belirtmişlerdir. Bu da kırsalda yaşayanların halen yemek pişirirken eski yöntemleri devam ettirdiğini göstermektedir. Demirel ve Karakuş (2019) Balıkesir yöresinin yeme içme kültürünün geçmişten bugüne değişimini incelemek amacıyla yaptıkları çalışmalarında geçmişte toprak kap, emaye tencere, bakır tencere ve alüminyum tencere kullanılırken, günümüzde ise daha çok çelik tencere, teflon tencere ve düdüklü tencere kullanılmakta olduğunu belirtmişlerdir. Yaptığımız çalışmada ise Balıkesir kırsal alanlarında halen çömlek ve toprak kapların kullanımının yaygın olduğu sonucu ortaya çıkmıştır. Bu da kırsal alanlarda halen mutfak gereçlerinin geçmişten izler taşıdığını göstermektedir. 
Tablo 3: Mutfak Kültürünün Sürdürülebilirliğine İlişkin Katılımcı Görüşleri

\begin{tabular}{|c|c|c|c|c|c|}
\hline$\frac{\frac{1}{2}}{3}$ & 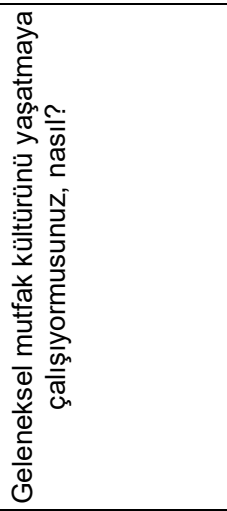 & 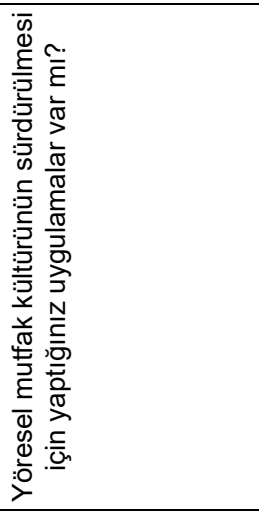 & 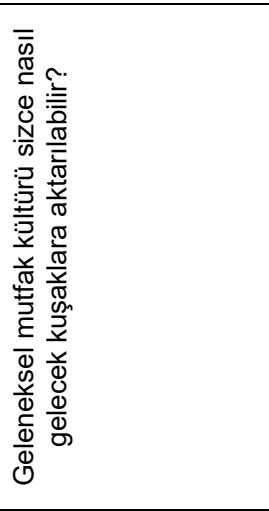 & 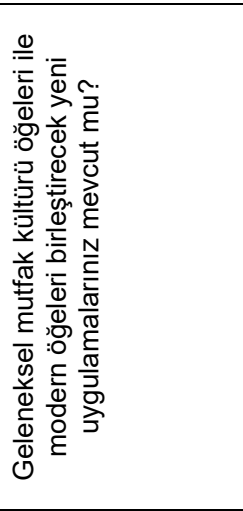 & 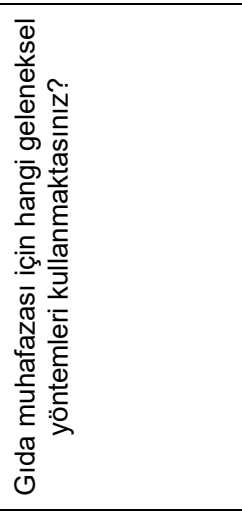 \\
\hline K1 & Çalışıyorum & Elimden geldiğince & $\begin{array}{c}\text { Biz isteriz gençler } \\
\text { istemiyor }\end{array}$ & Hayır & $\begin{array}{c}\text { Kurutma konserve } \\
\text { turşu } \\
\text { Salça, peynir }\end{array}$ \\
\hline K2 & $\begin{array}{l}\text { Yaşatmak } \\
\text { zorlaşıyor }\end{array}$ & Dükkân açtık & Tanıtım gerekli & Hayır & $\begin{array}{c}\text { Kurutma konserve } \\
\text { turşu }\end{array}$ \\
\hline K3 & $\begin{array}{l}\text { Yemekleri } \\
\text { yaparak }\end{array}$ & $\begin{array}{l}\text { Öğrenmek } \\
\text { isterlerse }\end{array}$ & Gençlere sevdirerek & Hayır & $\begin{array}{c}\text { Kurutma konserve, } \\
\text { peynir }\end{array}$ \\
\hline K4 & $\begin{array}{c}\text { Gelinime } \\
\text { öğreteceğim }\end{array}$ & Öğretiyorum & $\begin{array}{c}\text { Adetlerimizle ve } \\
\text { herkesi davet } \\
\text { ederek }\end{array}$ & Pişirme yöntemleri & Kurutma \\
\hline K5 & $\begin{array}{l}\text { Yer sofrasında } \\
\text { yemek yiyoruz }\end{array}$ & $\begin{array}{c}\text { Çevreme } \\
\text { öğretiyorum }\end{array}$ & $\begin{array}{c}\text { Çocuklara, } \\
\text { konuklara öğreterek }\end{array}$ & Bir fikrim yok & $\begin{array}{l}\text { Bez kese } \\
\text { konserve }\end{array}$ \\
\hline K6 & Hayır & $\begin{array}{l}\text { Çocuklarıma } \\
\text { öğretiyorum }\end{array}$ & $\begin{array}{l}\text { Çocuklarımıza } \\
\text { öğreterek }\end{array}$ & $\begin{array}{c}\text { Yeni yöntemlerle } \\
\text { pişiriliyor }\end{array}$ & $\begin{array}{c}\text { Konserve turşu } \\
\text { zeytin reçel }\end{array}$ \\
\hline K7 & $\begin{array}{l}\text { Evlatlarıma } \\
\text { misafirlerime } \\
\text { öğretiyorum }\end{array}$ & Öğretiyoruz & Bir fikrim yok & $\begin{array}{c}\text { Modern } \\
\text { yöntemlerle } \\
\text { yapıyoruz }\end{array}$ & $\begin{array}{l}\text { Kurutma } \\
\text { konserve }\end{array}$ \\
\hline K8 & İkram ederek & Öğretiyoruz & Bir fikrim yok & Bir fikrim yok & konserve \\
\hline K9 & $\begin{array}{l}\text { Çocuklarıma } \\
\text { öğreterek }\end{array}$ & $\begin{array}{l}\text { Misafirlere tariflerini } \\
\text { veriyorum }\end{array}$ & Bir fikrim yok & $\begin{array}{l}\text { Yeni yöntemlerle } \\
\text { pişiriliyor }\end{array}$ & $\begin{array}{c}\text { Konserve } \\
\text { Tarhana }\end{array}$ \\
\hline K10 & $\begin{array}{l}\text { Halen devam } \\
\text { ettirerek }\end{array}$ & Öğretiyorum & $\begin{array}{l}\text { Öğrenerek ve } \\
\text { öğreterek }\end{array}$ & Tat farkı var & $\begin{array}{c}\text { Konserve kurutma } \\
\text { salça tarhana }\end{array}$ \\
\hline K11 & $\begin{array}{c}\text { Yapmaya devam } \\
\text { ederek }\end{array}$ & Öğreteceğim & Öğreterek & $\begin{array}{c}\text { Modern } \\
\text { malzemeler ile } \\
\text { pişiriliyor, eski tat } \\
\text { yok }\end{array}$ & $\begin{array}{c}\text { Konserve kurutma } \\
\text { erişte tarhana } \\
\text { yufka }\end{array}$ \\
\hline K12 & $\begin{array}{l}\text { Yemekleri } \\
\text { yapıyoruz }\end{array}$ & $\begin{array}{l}\text { Öğretmeye } \\
\text { çalışıyorum }\end{array}$ & $\begin{array}{l}\text { İnternet üzerinden } \\
\text { tanıtılarak }\end{array}$ & $\begin{array}{c}\text { Modern } \\
\text { malzemeler ile } \\
\text { pişiriliyor, eski tat } \\
\text { yok }\end{array}$ & Konserve kurutma \\
\hline
\end{tabular}




\begin{tabular}{|c|c|c|c|c|c|}
\hline \multicolumn{6}{|c|}{ Tablo 3'ün devamı } \\
\hline K13 & Evet & $\begin{array}{c}\text { Özellikle bir } \\
\text { uygulama yok }\end{array}$ & Öğreterek & Hayır & Konserve \\
\hline K14 & $\begin{array}{l}\text { Çocuklarımıza } \\
\text { öğreterek }\end{array}$ & Öğretiyorum & $\begin{array}{c}\text { Çocukların } \\
\text { ilgilenmesi gerek }\end{array}$ & Eski tadı yok & $\begin{array}{l}\text { Kurutma turşu } \\
\text { salça reçel }\end{array}$ \\
\hline K15 & $\begin{array}{c}\text { Kültürümüzden } \\
\text { kopmamaya } \\
\text { çalışıyoruz }\end{array}$ & $\begin{array}{l}\text { Öğretmeye } \\
\text { çalışıyorum }\end{array}$ & $\begin{array}{l}\text { Akademik } \\
\text { çalışmalarla }\end{array}$ & Bir fikrim yok & $\begin{array}{c}\text { Konserve erişte } \\
\text { salça }\end{array}$ \\
\hline K16 & $\begin{array}{l}\text { Dışarda ocakta } \\
\text { yemek yapıp } \\
\text { herkese ikram } \\
\text { ediyoruz }\end{array}$ & Öğretiyoruz & $\begin{array}{l}\text { Çocuklara } \\
\text { öğreterek }\end{array}$ & Bir fikrim yok & $\begin{array}{c}\text { Konserve } \\
\text { kurutma reçel } \\
\text { erişte }\end{array}$ \\
\hline K17 & $\begin{array}{l}\text { Evimde de } \\
\text { devam } \\
\text { ettiriyorum }\end{array}$ & Öğretiyoruz & $\begin{array}{l}\text { Evlerde yapılarak } \\
\text { çocuklara } \\
\text { öğretilerek }\end{array}$ & Hayır & $\begin{array}{c}\text { Tarhana erişte } \\
\text { bulgur }\end{array}$ \\
\hline K18 & Öğretiyoruz & Hayır & Öğreterek & Bir fikrim yok & $\begin{array}{l}\text { Konserve } \\
\text { kurutma }\end{array}$ \\
\hline K19 & Hayır & Öğretiyoruz & $\begin{array}{l}\text { Gençler istekli } \\
\text { değil isteseler } \\
\text { anlatırız }\end{array}$ & Hayır & $\begin{array}{c}\text { Konserve } \\
\text { kurutma erişte } \\
\text { salça }\end{array}$ \\
\hline K20 & Hayır & İzleyen öğrenir & $\begin{array}{c}\text { Gençler istekli } \\
\text { değil isteseler } \\
\text { anlatırız }\end{array}$ & Hayır & $\begin{array}{l}\text { Kurutma } \\
\text { konserve }\end{array}$ \\
\hline
\end{tabular}

Mutfak kültürünün sürdürülebilirliğine ilişkin sorulardan biri olan "Geleneksel mutfak kültürünü yaşatmaya çalışıyor musunuz, nasıl? sorusuna ilişkin görüşlerden bazıları şu şekildedir; K8, K9, K14, geleneksel mutfak kültürü öğelerini çocuklarına öğreterek yaşatmaya çalıştıklarını, K4 ve K7 çocuklarına, gelinlerine ve misafirlerine öğrettiklerini, K6, K19 ve K20 ise geleneksel mutfak kültürünü yaşatmak için her hangi bir çaba göstermediklerini belirtmişlerdir. Katılımcıların çoğunluğunu mutfak kültürü öğelerini başkalarına öğreterek aktardıklarını belirtmişlerdir. Temelde bu konuda ev kadınlarının yöresel yemekleri yaşatabilmek için istekli oldukları bu durumun da aslında turizmde yaşanan ürün çeşitlendirme sorunu için olumlu kullanılabilecek bir durum olduğu söylenebilir. Ayaz ve Çobanoğlu'nun (2017) yapmış oldukları çalışmalarında da ev kadınlarının turistler için yöresel yemek pişirme isteği içerisinde oldukları tespit edilmiştir. Bu da yöresel mutfak kültürünün sürdürülebilirliği için önemli bir adımdır.

"Gıda muhafazası için hangi geleneksel yöntemleri kullanmaktasınız? sorusuna ilişkin verilen cevaplarda katılımcılar konserve, kurutma, tarhana, erişte ve reçel olarak gıda muhafazası sağladıklarını belirtmişlerdir. K1,K4, K10, K11, K12, K14, K15, K16 ise geleneksel yöntemlerin yanı sıra dondurarak gıda muhafazası yöntemini de kullandıklarını belirtmişlerdir. Çakıcı ve Zencir (2018) yaptığı çalışmada benzer bir sonuç bulmuştur. Araştırma alanı olan köyde yaşayanların gıda maddelerinin fazlasının kış için gıda saklama yöntemleri ile muhafaza edildiği anlaşılmıştır.

Tablo3 incelendiğinde genel olarak geleneksel mutfak kültürü öğelerini yaşatmak için 'öğretme' kavramı ön plana çıkmaktadır. Katılımcıların çoğu gerek çocuklarına gerekse misafirlerine öğreterek bu değerlerin sürdürülmesine katkı sunmaktadırlar. 
Sürücüoğlu ve Akman (1998) Türk Mutfak kültürünün zenginleşmesinde, geleneksel Türk misafirperverliğinin önemli bir yeri olduğunu belirtmektedir. Yapılan bu çalışmada da katılımcıların misafirlerine mutfak kültürünü aktarma amacı ile "öğrettikleri" sonucu ortaya çıkmıştır. Bu durumda mutfak kültürü ve misafirperverliğin çift yönlü bir ilişki içerisinde olduğunu ve birbirlerini etkilediklerini göstermektedir. Özkan (2020) yaptığı çalışmada yapılan yöresel yemeklerin sunumu ve yapımında tüm köy halkının birlikte hareket ettiği dolayısıyla yöresel yemeklerin kültürümüzde yer alan imece usulünü güçlendirdiği birlikte hareket etme ve misafirperverliği geliştirdiğini vurgulamaktadır.

Katılımcıların bir kısmı gençlerin mutfak kültürü ile ilgili konularda ilgisiz olduklarını ve öğrenmeye istekli olmadıklarını belirtmişlerdir. Bununla birlikte Şanlıer vd.,'nin (2012)gençlerin Türk mutfak kültürüne bakış açısını belirlemek için yaptığı çalışmada gençlerin, Türk mutfağının unutulduğunu düşündüğünü tespit etmiştir. Bu göstermektedir ki hem gençler arasında hem yetişkinler arasında mutfak kültürünün unutulduğuna dair algı mevcuttur. Geleneksel mutfak kültürü öğelerini gelecek kuşaklara aktarabilmek için öncelikle gençlerin bu değerleri tanıması ve sahip çıkması gerekmektedir. Her iki sonuç da bu kapsamda önem arz etmektedir.

\section{Tablo 4: Yöresellik ve Geçmişten İzlere Yönelik Katılımcı Görüşleri}

\begin{tabular}{|c|c|c|c|c|}
\hline 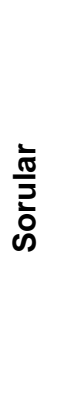 & 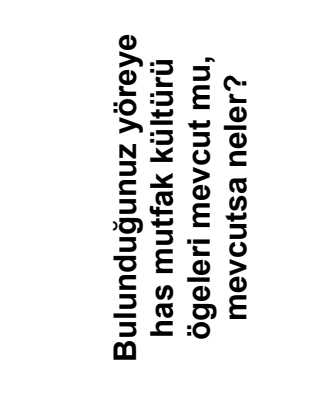 & 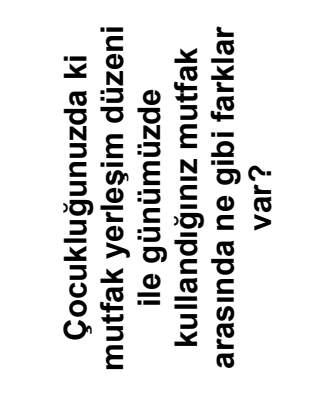 & 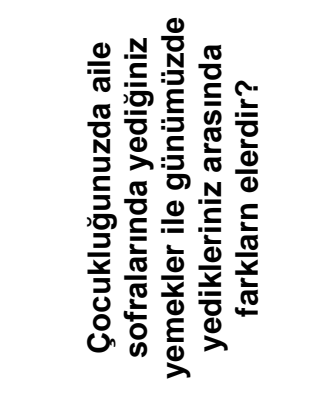 & 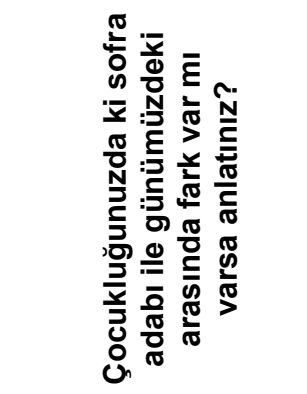 \\
\hline $\mathrm{K} 1$ & $\begin{array}{c}\text { Sura (kaburga } \\
\text { dolması), saraylı tatlısı }\end{array}$ & Fark yok & $\begin{array}{l}\text { Farklı ateşte pişerdi } \\
\text { tadı başka olurdu }\end{array}$ & Fark yok \\
\hline $\mathrm{K} 2$ & Kara tava, sac, güveç & $\begin{array}{c}\text { Her şeyimiz } \\
\text { bahçemizdendi }\end{array}$ & $\begin{array}{l}\text { Pişme süresi daha } \\
\text { uzundu, daha } \\
\text { lezzetliydi }\end{array}$ & Saygı yok \\
\hline K3 & $\begin{array}{l}\text { Turp otu } \\
\text { Hardal otu }\end{array}$ & Yer sofrası vardı & $\begin{array}{c}\text { Güveç kullanılırdı, } \\
\text { daha lezzetliydi }\end{array}$ & Fikrim yok \\
\hline $\mathrm{K} 4$ & $\begin{array}{c}\text { Acı filiz, rezene, cibez, } \\
\text { gombala }\end{array}$ & $\begin{array}{c}\text { Eskiden ayrı mutfak } \\
\text { yoktu }\end{array}$ & $\begin{array}{l}\text { Lezzet daha iyiydi } \\
\text { pişirme daha zordu }\end{array}$ & Yer sofrası vardı \\
\hline K5 & Bakır kap & $\begin{array}{l}\text { Hala yer sofrasında } \\
\text { yemek yiyoruz }\end{array}$ & $\begin{array}{c}\text { Yemek çeşidi daha } \\
\text { azdı }\end{array}$ & Yer sofrası vardı \\
\hline K6 & Kapak kesme, sura & $\begin{array}{c}\text { Eskiden ayrı mutfak } \\
\text { yoktu }\end{array}$ & Şimdikilerin tadı kötü & Yer sofrası vardı \\
\hline K7 & $\begin{array}{c}\text { Sura, kapak kesme, } \\
\text { kaldirek }\end{array}$ & $\begin{array}{c}\text { Eskiden ayrı mutfak } \\
\text { yoktu }\end{array}$ & Lezzet fakrı var & $\begin{array}{c}\text { Yer sofrası tek tabak } \\
\text { vardı }\end{array}$ \\
\hline $\mathrm{K} 8$ & Sura, kapakkesme & $\begin{array}{c}\text { Eskiden ev içi mutfak } \\
\text { yoktu }\end{array}$ & $\begin{array}{c}\text { Dışarda taş ocaklarda } \\
\text { pişerdi, tadı daha } \\
\text { güzeldi }\end{array}$ & $\begin{array}{c}\text { Yer sofrası tek tabak } \\
\text { vardı }\end{array}$ \\
\hline
\end{tabular}




\begin{tabular}{|c|c|c|c|c|}
\hline K9 & Bazlama & Bir fikrim yok & $\begin{array}{l}\text { Daha doğal ve } \\
\text { sağlıklıydı }\end{array}$ & $\begin{array}{c}\text { Eskiden } 8 \text {-9 kişi } \\
\text { otururduk }\end{array}$ \\
\hline K10 & Kapari turşusu & $\begin{array}{l}\text { Eskiden mutfak } \\
\text { bahçedeydi şimdi evde }\end{array}$ & $\begin{array}{l}\text { Pişirme yöntemi, } \\
\text { lezzet ve görünüş } \\
\text { farklı }\end{array}$ & $\begin{array}{c}\text { Fark yok, sini de yer } \\
\text { sofrasında }\end{array}$ \\
\hline K11 & Çömlekte kuru fasulye & $\begin{array}{c}\text { Eskiden mutfak } \\
\text { bahçedeydi şimdi evde }\end{array}$ & $\begin{array}{c}\text { Tat farkı var } \\
\text { Emayelerde, } \\
\text { kazanlarda bahçede } \\
\text { pişirilirdi, }\end{array}$ & $\begin{array}{l}\text { Eskiden yer sofrası } \\
\text { şimdi masada }\end{array}$ \\
\hline K12 & Un çorbası, keşkek & $\begin{array}{l}\text { Eskiden mutfak } \\
\text { bahçedeydi şimdi ayrı }\end{array}$ & $\begin{array}{l}\text { Daha sağlıklı ve } \\
\text { lezzetliydi }\end{array}$ & $\begin{array}{c}\text { Eskiden yer sofrası } \\
\text { şimdi masada ayrı } \\
\text { tabakta }\end{array}$ \\
\hline K13 & Bir fikrim yok & Fark yok & $\begin{array}{c}\text { Taş ocaklarda güveçte } \\
\text { yapılırdı, tadı daha } \\
\text { güzeldi }\end{array}$ & $\begin{array}{c}\text { Eskiden yer sofrası } \\
\text { şimdi masa }\end{array}$ \\
\hline K14 & Bakır kap, sac & $\begin{array}{l}\text { Eskiden mutfak } \\
\text { bahçedeydi }\end{array}$ & $\begin{array}{l}\text { Her şeyin tadı daha } \\
\text { lezzetliydi }\end{array}$ & $\begin{array}{c}\text { Sofrada büyüklere } \\
\text { saygı vardı }\end{array}$ \\
\hline K15 & Bakır kap & $\begin{array}{l}\text { Eskiden mutfak } \\
\text { bahçedeydi }\end{array}$ & $\begin{array}{c}\text { Tek tepsinin içinden } \\
\text { yerdik, şimdi } \\
\text { masadayız } \\
\end{array}$ & $\begin{array}{c}\text { Eski saygı yok, } \\
\text { sofrada sohbet } \\
\text { olmazdı }\end{array}$ \\
\hline K16 & Sura, kapak kesme & Fark yok & $\begin{array}{l}\text { Eskiden yer sofrası } \\
\text { vardı şimdi masa }\end{array}$ & $\begin{array}{l}\text { Eskiden yer sofrası } \\
\text { vardı şimdi masa }\end{array}$ \\
\hline $\mathrm{K} 17$ & Bakır kap, tandır & $\begin{array}{l}\text { Eskiden mutfak } \\
\text { bahçedeydi }\end{array}$ & $\begin{array}{c}\text { Yer sofrası vardı } \\
\text { Şimdi tabaklar ayrıldı }\end{array}$ & $\begin{array}{c}\text { Yer sofrasında } \\
\text { büyüdük, tabaklar } \\
\text { ayrıldı }\end{array}$ \\
\hline K18 & $\begin{array}{l}\text { Düğün mantısı, sura, } \\
\text { kapak kesme }\end{array}$ & Bir fikrim yok & $\begin{array}{l}\text { Eskiden nasılsa aynı } \\
\text { yapmaya çalışıyoruz }\end{array}$ & $\begin{array}{l}\text { Sofra düzeni } \\
\text { değişmedi }\end{array}$ \\
\hline K19 & $\begin{array}{c}\text { Düğün mantısı, kapak } \\
\text { kesme }\end{array}$ & Yer sofrası vardı & $\begin{array}{c}\text { Fark yok öğrendiğimiz } \\
\text { gibi yapmaya } \\
\text { çalışıyoruz }\end{array}$ & Masa düzeni yoktu \\
\hline K20 & Kapak kesme & $\begin{array}{c}\text { Şimdi masada yemek } \\
\text { yeniyor }\end{array}$ & $\begin{array}{l}\text { Çok fark var, daha } \\
\text { lezzetliydi }\end{array}$ & Fark yok \\
\hline
\end{tabular}

Her bölgenin kendine özgü pişirme teknikleri ve beslenme kültürü bulunmaktadır (Maviş, 2003:58). Bu konuda derinlemesine bilgi almak için oluşturulan "Yöresellik ve Geçmişten İzler" teması kapsamında "Bulunduğunuz yöreye has mutfak kültürü öğeleri mevcut mu?" sorusu sorulmuştur. Verilen cevaplar incelendiğinde, katılımcıların zihninde genel olarak yöresel yemekler ve kullanılan kaplar canlanmıştır. Katılımcılardan K1, K6, K7, K8, K16, K18 yöresel bir yemek olan Sura'yı (kaburga dolması), K6, K7, K8, K16, K18, 19, K20 ise kapak kesme (çiğbörek) olarak cevap vermişlerdir. Türkiye'de bölgeler arasında değişik çeşitte yemek türlerini bulmak mümkündür. Güler (2010) hamur işlerinin tüketiminin oldukça yaygın olma sebebini tarımsal yapıya bağlamıştır. Yaptığı çalışmada "Mantı" en sevilen hamur işi yemek olarak belirtilmekteyken çalışmamızda ise "çiğ börek" ön plana çıkmaktadır.

"Çocukluğunuzda ki mutfak yerleşim düzeni ile günümüzde kullandığınız mutfak arasında ne gibi farklar var?" sorusuna verilen cevaplarda; K1, K2, K13, K16 geçmişten günümüze fark olmadığını, K2, K8, K10, K11, K12, K14, K15, K17 mutfak yerleşim düzeninin eskiden bahçede yer aldığını belirtmişlerdir. Serçelioğlu (2014) 
geçmişte Erzurum evlerinde de yer alan mutfak ve tandırların diğer illerdekinden farklı olarak evlerinin zemin katında yer aldığını belirtmektedir. Demirel ve Karakuş (2019) yapmış oldukları çalışmalarında ise bu çalışma ile benzer olarak Balıkesir yöresinde geçmişten bu güne mutfak yerleşim düzeninin konumunun değiştiğini belirtmişlerdir.

"Çocukluğunuzdaki sofra adabı ile günümüzdeki arasında fark var mı? Varsa anlatınız?" sorusuna yönelik öne çıkan katılımcı cevapları ise;

K4, K5, K6, K11, K13 "eskiden yer sofrası vardı" şeklinde cevap verirken, K7, $\mathrm{K} 8, \mathrm{~K} 12, \mathrm{~K} 13, \mathrm{~K} 16, \mathrm{~K} 17$ "yer sofrasında ayrı tabak olmadan yemek yenirdi" şeklinde olmuştur. K2, K14, K15 ise şimdiki sofralarda eski saygının olmadığını belirtmişlerdir.

Tabloya göre katılımcılar (K2,K3, K4, K7, K8, K10, K11, K12, K13, K14, K20) geçmişte yemeklerin daha az çeşit olmasının yanı sıra daha sağlıklı ve lezzetli olduklarını belirtmişlerdir. Özkoçak (2015) da çalışmasında seksenli yıllardan sonra bitki ve hayvan yetiştiriciliğinde büyüme hormonları, antibiyotikler ve suni gübre kullanımının oldukça fazlalaştığını; konserve, hazır gıdaların ve gıda katkı maddelerinin piyasaya sürülmesi gibi etkenlerin mutfak kültürünü etkilediğini belirtmiştir. Geçmişten bugüne algılanan bu sağlık ve lezzet değişiminin sebebini artan hazır gıda tüketimi ve tarımsal faaliyetlerdeki değişim olarak belirtilebilir.

\section{Sonuç ve Öneriler}

Mutfak kültürü insan hayatında ve kültürel etkileşimde önemli izler taşır. Yemeklerin hazırlanacağı malzemelerin seçimi, özel günlerde hazırlanan yemek tercihleri, yemeğin hazırlandığı araç gereç ve mutfak düzenlemesi gibi unsurlar kültürel özelliklere göre de çeşitlilik göstermektedir.

Yapılan bu çalışma kırsalda yaşayanların halen yemek pişirirken eski yöntemleri devam ettirdiğini göstermektedir. Örneğin yemek pişirme araç gereci olarak çömlek, güveç yani toprak kapları günümüzde de kullanılmaktadır. Bu da kırsal alanlarda yöresel mutfak kültürü kavramının halen uygulanmakta olduğunu göstermektedir. Çalışmada ayrıca Burhaniye Madra dağı eteklerinde yer alan kırsal da mutfak kültürü öğeleri olarak yöresel yemekler ve araç gereçler ön plana çıkmış, bunların da sura, kapaktan kesme, düğün mantısı ve bakır kap olduğu tespit edilmiştir.

Araştırma sonuçlarına göre geçmişte mutfak yerleşim düzeninin daha çok bahçede yer aldığı, ev içerisinde mutfak yerleşim düzeninin ayrı bir alan olarak bulunmadığını belirtebiliriz. Geçmişte yemeklerin daha çok bahçede ocak ya da tandırda pişirildiği, yemek çeşidinin daha az ve yemek düzeninde de günümüze göre farklılıklar olduğu görülmektedir. Geçmişte yer sofrasında ayrı tabak olmadan tek tepsiden yemek yenirdi. Bununla beraber araştırma kapsamında geçmişte yemeklerin günümüzde ki yemeklere göre daha lezzetli olduğu sonucu da çıkmıştır. Geçmişte yemek pişirmede bakır ve güveç kapların daha çok kullanılıyor olmasının yemeklerin daha lezzetli olmasını sağladığı sonucu da çıkarılabilir.

Araştırmada geleneksel mutfak kültürünün gelecek nesillere aktarımı için çocuklarımıza ve gençlere bu kültürü öğretmenin gerekliliği vurgulanmış ancak gençlerin bu konuda pek istekli olmadıkları söylenmiştir. Ayrıca katılımcılar şimdiki sofralarda gençlerden bekledikleri eski saygının olmadığını belirtmişlerdir.

Araştırma sonuçları doğrultusunda geliştirilebilecek öneriler şunlardır; 
- Yöresel mutfak kültürünün sürdürülebilirliğini sağlamak ve turizm sektörüne katkı sağlayacak hale getirebilmek için her bir bölgeye özgü özele indirgenmiş tanıtım çabaları geliştirilmelidir. Özellikle kırsalda yaşayan ev kadınlarının hem çocuklarına hem de kırsal ile bağlantısı olan gençlere yöresel mutfak aktarımını kolaylaştıracak unsurların geliştirilmesi gerekmektedir.

- Kırsal alanlarda mutfak kültürü ve yöresel yemekler temalı festivaller düzenlenerek tanıtım ve sürdürülebilirlik sağlanmalıdır.

- Mutfak kültürünü yansıtan ve bu konuda bilgi verilen, mutfak araç ve gereçlerinin sergilendiği alanlar oluşturulmalıdır.

- Yerel yönetimlerin katıımı ile kaybolmaya yüz tutmuş yöresel yemekler ile ilgili kurslar düzenlenebilir.

- Yörelere has yemekler ve gıda saklama yöntemleri araştırılarak kayıt altına alınmalıdır. Bölge bazında yöresel yemeklerin analizi yapılarak bu yemeklerin standart reçetelerinin çıkartılması ve bölge restoranlarında sunulması sağlanmalıdır.

- Yöresel mutfak kültürünün sürdürülebilmesinde yerel gıda sistemlerinin desteklenmesi ve yöre halkının ek gelir elde ederek sisteme dâhil edilmesi gerekmektedir. Özellikle ev kadınlarının turizmde ürün çeşitliliği sağlanması adına yöresel yemek üretimini turistlere yönelik yapabilecekleri istihdam politikalarının geliştirilmesi gerekmektedir.

- Mutfak kültürü sürdürülebilirliğinde kırsal alanda yaşayan kadınların önemli payı bulunmakla beraber mutfak düzeninden hazırlanan yemeklere kadar pek çok mutfak kültürü öğesinde geçmişten bu güne değişik olmaktadır. Kırsal alandaki kadınlar hazır gıda tüketimine yönelmek yerine yöresel gıdalarını hazırlamaları teşvik edilmelidir. Bu sayede mutfak kültürünün gelecek kuşaklara aktarımı sağlanabilecektir.

Bu araştırma, zaman ve maliyet açısından Burhaniye kırsalı ile sınırlı tutulmuş olup araştırmanın verileri Madra Dağı eteklerinde yer alan köylerde yaşayan yerel halktan elde edilmiştir. Çalışma yöresel mutfak kültürü konusunda ön plana çıkan kırsal alanlarda yapılabileceği gibi bu yörelerin destinasyon yönetimi ve pazarlayıcıları üzerine de yapılabilir. Bu sayede farklı örneklem gruplarıyla karşılaştırmalar yapılıp farklılıklar ve benzerlikler tespit edilip daha ayrıntılı öneriler geliştirilebilir. Ayrıca çalışmanın farklı bölgelerde tekrar edilmesinin çalışmayı destekleyici ve tamamlayıcı nitelikte olacağı düşünülmektedir.

\section{Kaynakça}

Ayaz, N. ve Çobanoğlu, S. (2017). Ev Kadınlarının Turizm Amaçlı Yöresel Yemek Üretimine Bakış Açıları: Bartın İli Örneği, Karabük Üniversitesi Sosyal Bilimler Enstitüsü Dergisi, 7 (1), ss. 413-427

Babat, D., Gökçe, F. ve Varışlı, A. (2017). Hatay Mutfak Kültürünün Sürdürülebilirliğinde Yöresel Yiyecek Üreticilerinin Rolü, 1st International Sustainable Tourism Congress, November 23-25 2017, Kastamonu Üniversitesi Turizm Fakültesi, Kastamonu, ss. 816-830.

Bozok, D.,Kahraman, K. (2015). Kırsal Turizmde Yöresel Yemek Kültürünün Rolü: Balıkesir, International Journal of Social and Economic Sciences 5 (1), ss. 8590.

Çakıcı, H. Zencir, E. (2018), Unutulmaya Yüz Tutmuş Mutfak Kültürleri: Çakırözü Köyü Örneği, Journal of Tourism and Gastronomy Studies 6(3), ss. 285-297.

Coşkun, R.,Altunışık, R., Bayraktroğlu, S. ve Yıldırım, E. (2015), Sosyal Bilimlerde Araştırma Yöntemleri, 8. Baskı, Sakarya Kitabevi, Sakarya. 
Çomaklı, Z. (2011). Erzurum Geleneksel Mutfak Kültürü ve Yemekleri, III. Uluslararası Doğu Anadolu Bölgesi Geleneksel Mutfak Kültürü ve Erzurum Yemekleri Sempozyumu, ss. 333-343, Erzurum.

Demirel, H. ve Karakuş, H. (2019). Balıkesir Yeme İçme Kültürü ve Değişimi Üzerine Bir Alan Araştırması. Journal of Tourism and Gastronomy Studies, 7 (2), ss. 1383-1404.

Demirel H., Ayyıldız, S. (2017). Mutfak Kültürü ve Değişimi; Giresun İli Örneği, Journal of Tourism and Gastronomy Studies, 5(4),ss. 280-298.

Doğdubay, M. ve Giritlioğlu, İ. (2011). Mutfak Turizmi, N. Hacıoğlu ve C. Avcıkurt (Ed.),Turistik Ürün Çeşitlendirmesi içinde (ss. 433-456), Nobel Akademik Yayıncılık, Ankara.

Durlu Özkaya, F. (2009). Türk mutfağında zeytinyağı”, Zeytinyağı, (Ed.) Fahrettin Göğüş, Mücahit Taha Özkaya, Semih Ötleş, Bölüm 15, ss. 252-263, Eflatun Yayınevi, Ankara.

Güneş, G, Ülker, H. İ. ve Karakoç, G. (2008), "Sürdürülebilir Turizmde Yöresel Yemek Kültürünün Önemi”, II. Ulusal Gastronomi Sempozyumu ve Sanatsal Etkinlikler, 10-11 Nisan 2008, Antalya.

Güler, S. (2010) "Türk Mutfak Kültürü ve Yeme İçme Alışkanlıkları", Dumlupınar Üniversitesi Sosyal Bilimler Dergisi, 26. ss.24-30.

Gvion, L.,andTrostler, N. (2008). From Spaghetti And Meatball Sthrough Hawaiian Pizza to Sushi: The Changing Nature of Ethnicity in American Restaurants. The Journal of Popular Culture, 41(6),pp. 950-974.

Henderson, J. (2009). Food Tourism Reviewed. British Food Journal, 111(4), pp.317326.

Köşklü, Z. (2005). "Eski Erzurum Mutfağında Tandır: Yapılışı, Kullanımı ve Doğu Anadolu'daki Yeri Üzerine". Sosyal Bilimler Dergisi, 2005/2, ss. 155-178.

Lopez, X. A. A. and Martin, B. G. (2006). Tourism and quality agro food products: An opportunity for the Spanish country side. Tijdschrift voor Economische en Sociale Geografie, 97(2), pp. 166-177.

Maviş, F. (2003), Endüstriyel Yiyecek Üretimi, Ankara: Detay Yayıncılık

Morse, J. M. (1995), 'The Signifance of Saturation', Qualitative Health Research, 5(2), May,pp. 147-149.

Neuman, W. L. (2012). Toplumsal Araştırma Yöntemleri: Nicel ve Nitel Yaklaşımlar I Cilt (5. Basım). İstanbul:Yayın Odası.

Önçel, S.(2015). Türk Mutfağı ve Geleceğine İlişkin Değerlendirmeler, Journal of Tourism and Gastronomy Studies 3(4), ss. 33-44.

Patton, M. Q. (2005). Qualitative Research. New York: John Wiley\&Sons, Ltd.

Özkan, Ç. (2020). Sürdürülebilir Gastronomi Turizmi Kapsamında Somut Olmayan KültürelMiras Unsuru: Hıdırellez Pilavı Üzerine Bir Araştırma, Türk Turizm Araştırmaları Dergisi, 4(1), ss. 361-373.

Savgın, E. C. ve Zengin, B. (2019). "Çiftlik Turizmi Faaliyetlerinin Geleneksel Mutfak Kültürü Sürdürülebilirliği Açısından Değerlendirilmesi”. Journal of Tourism and Gastronomy Studies, 7 (1), ss.484-504.

Serçeoğlu, N. (2014). Yöre Halkının Mutfak Kültürünü Tanıma Durumunun Tespit Edilmesi: Erzurum İli Örneği, Journal of Tourism and Gastronomy Studies 2(4), ss. $36-46$.

Şanlıer N., Cömert M., Durlu Özkaya F. (2012) Gençlerin Türk Mutfağına Bakış Açısı Millî Folklor,24(94), ss.. 152-161.

Tarım ve Köy İşleri Bakanlığı, (2011). Kırsal Kalkınma Planı 2010-2013, Ankara.

Yıldırım, A. ve Şimşek, H. (2008), Nitel Araştırma Yöntemleri, Seçkin Yayınevi, 6. Baskı,

Ankara. 
T.C.

BALIKESIR ÜNIVERSITESI

SOSYAL VE BEŞERI BILIMLER ETIK KOMISYONU

ONAY BELGESI

Balıkesir Üniversitesi Burhaniye Meslek Yüksekokulu Müdürü Prof.Dr.Mehmet Oğuzhan ILBAAN'ın "nerede o eski mutfaklar" isimli çalışmanın alan araştırması (anket) gerçekleştirilebilmesi ile ilgili etik kurul onay belgesi isteği komisyonumuzca değerlendirilmiş ve etik açıdan uygun bulunmuştur. 09.06.2020 